\title{
MICROBIAL COMMUNITY DURING BIOREMEDIATION EXPERIMENTAL ON OIL SPILL IN COASTAL OF PARI ISLAND
}

\author{
Lies Indah Sutiknowati \\ Research Center for Oceanography, Indonesian Institute of Science, Jakarta 14430, Indonesia, \\ E-mail: lies_indah@yahoo.com.sg
}

\begin{abstract}
There is an information how to identify hydrocarbon degrading bacteria for bioremediation of marine oil spill. We have Bioremediation treatment for degradation of oil spill on Pari island and need two kind of experiment there are tanks experiment (sampling 0 to 90 days) and semi enclosed system (sampling 0 to 150 days). Biostimulation with nutrients ( $\mathrm{N}$ and $\mathrm{P}$ ) was done to analyze biodegradation of hydrocarbon compounds. Experiment design using fertilizer Super IB and Linstar will stimulate bacteria can degrade oil, n-alkane, and alkane as poly aromatic hydrocarbon. The bacteria communities were monitored and analyzed by Denaturing Gradient Gel Electrophoresis (DGGE) and Clone Library; oil chemistry was analyzed by Gas Chromatography Mass Spectrometry (GCMS). DNA (deoxyribonucleic acid) was extracted from colonies of bacteria and sequence determination of the 16S rDNA was amplified by primers U515f and U1492r. Strains had been sequence and had similarity about $90-99 \%$ to their closest taxa by homology Blast search and few of them suspected as new species. The results showed that fertilizers gave a significant effect on alkane, PAH and oil degradation in tanks experiment but not in the field test. Dominant of the specific bacteria on this experiment were Alcanivorax, Marinobacter and Prosthecochloris.
\end{abstract}

Keywords: Bioremediation, Biostimulation, DGGE, PAH, Pari Island

\section{INTRODUCTION}

Oil spills are global problem Anticipation to minimalize the impact. Bioremediation is needed, but no report that this method is effective in tropical waters Bioremediation, which is accomplished by adding exogenous microbial populations or stimulating indigenous ones, attempts to raise the rates of degradation found naturally to significantly higher rates (Watanabe, 2001). Many oil-degrading bacteria have been isolated and their degradation potential investigated. Most of bioremediation studies have been carried out using pure-cultures and the roles of these bacteria in a natural environment remain substantially unknown (Harayama et al., 1999).
The study of identification of bacteria is important in microbial ecology, especially with molecular techniques (Watanabe et al., 2003) In particular, analysis of the microbial communities that take part in in-situ hydrocarbon biodegradation activities has been a challenge to microbiologist. Interest in this area has been catalyzed by the rapid advancement of molecular ecological methodologies (MacNaughton et al., 1999). Hydrocarbon utilizing microorganisms are ubiquitously distributed in the marine environment following oil spills. These microorganisms are naturally degraded numerous contaminating petroleum hydrocarbons and cleansing the oceans of oil pollutants. 
Many microorganisms capable of degrading petroleum components have been isolated and few of them seem to be important for petroleum biodegradation in natural environments. They are members of the genus Alcanivorax (Yakimov et al., 1998; Harayama et al., 1999) and Thalassospira (Lopez-Lopez et al., 2002; Watanabe et al., 2006) became predominant in the enrichment cultures.

The application of fertilizer increased rates of biodegradation 3-5 times. Multiple regression models showed that the effectiveness of bioremediation depending upon the amount of nitrogen delivered, the concentration of oil, and time (Atlas et al., 1995). Smaller molecular weight is readily biodegraded in marine environments. Aromatics with one, two or three aromatic rings are also efficiently biodegraded; however, those with four or more aromatic ring are quite resistant to biodegradation.

This project is examining the mechanism of the crude oil degradation by tropical bacteria and to develop methods for oil spill cleanup using bacterial function. RCO team has responsibility to do field study. The purpose of this research was to identify hydrocarbon degrading bacteria which grown on oil and Poly Aromatic Hydrocarbons. Sample was taken from Simulator Tanks in Pari Island (Figure 1), under Research Center for Oceanography, Indonesian Institute of Sciences, Jakarta, Indonesia on July 2006. This observation suggests that Alcanivorax, Marinobacter and Prosthecochloris play an important role in the degradation of petroleum PAHs in marine environment. The objectives of this research were to monitor the changes of microbial succession in Pari Island experiment and to determine type of microbe stimulated by nutrient addition.

\section{METHODS}

\subsection{Study Area of Research}

Experimental tanks and semi enclosed system was located in the Pari Island, Seribu islands (Jakarta Bay) on the period of 2006-2008. Sampling designed for this research was located in laboratorium and area about $1 \mathrm{~km}$ away from main land of Pari island.

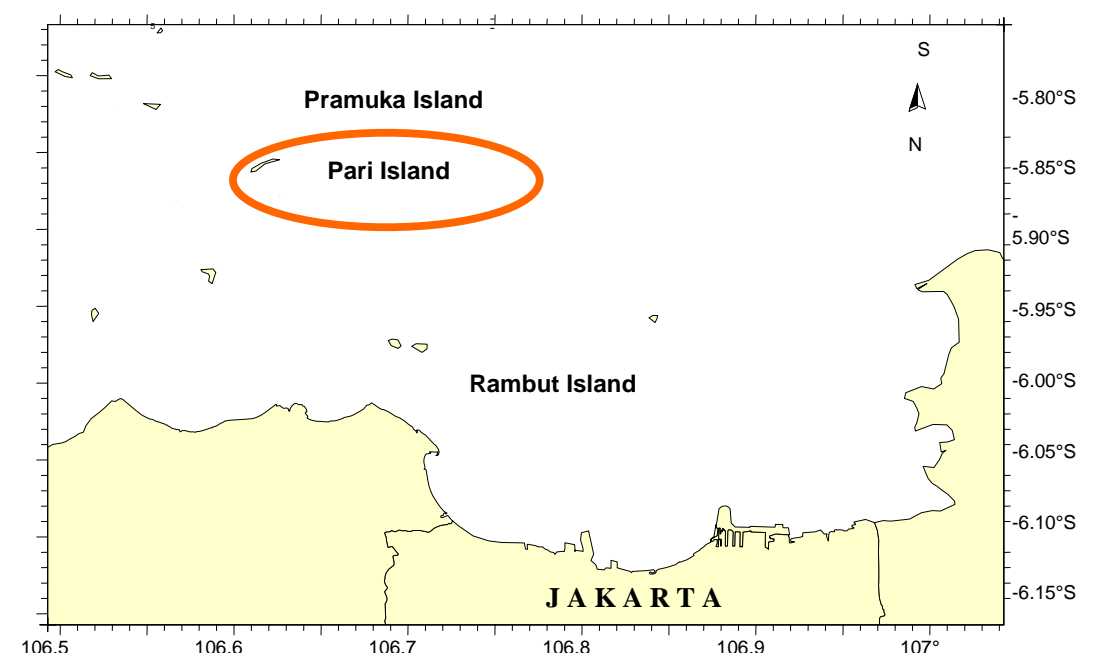

Figure 1. A map showing sampling locations for bioremediation of marine oil spill experiment in Pari island 


\subsection{Experiment Tanks}

A pair of tanks $(1.5 \mathrm{~m}$ long by $1 \mathrm{~m}$ wide by $1 \mathrm{~m}$ deep) was set up to simulate the biodegradation of oil in field laboratory Pari Island (Figure 2). Each tank was added a sieve and partially filled of gravel grains (sediments). Oil polluted cobble-stones sampled from a beach contaminated were then put on all of the gravel (Maki et al., 1999; Kasai et al., 2002). Seawater was changed continuously every 2 days and monitored temperature, salinity, $\mathrm{DO}$ and $\mathrm{pH}$.
Experimental design using crude oil, 2 different fertilizers and concentration (10 gr crude oil, super IB 20 gr and 2 gr, Linster 2 gr and 0.2 gr) and 3 controls (only oil, only fertilizer, and without oil and fertilizers), showed as A: A1-A2, B: B1-B2, C1, C2, and C3 (Table 1 and Figure 3). Sample of $50 \mathrm{gr}$ gravel from each tank was taken for isolation microbes by DGGE analyses, for microbial community changes, and monitoring disappearance of crude oil by GCMS on July 2006.

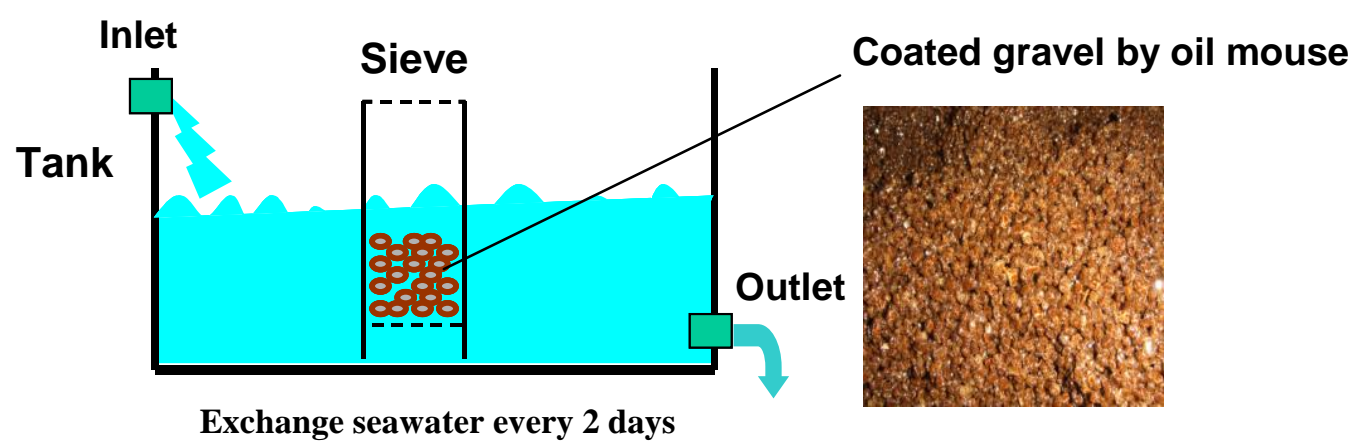

Figure 2. Experiment tanks which set up for simulate of oil biodegradation in field Laboratory Pari Island

Table 1. Treatment for 60-90 days using crude oil, two different fertilizers and concentration

\begin{tabular}{|c|c|c|c|}
\hline TREATMENT & ARABIAN LIGHT & \multicolumn{2}{|c|}{ FERTILIZER } \\
\hline 60-90 days & CRUDE OIL & $\begin{array}{c}\text { SUPER IB } \\
\text { (Nitrogen source) }\end{array}$ & $\begin{array}{c}\text { LINSTER } \\
\text { (Phosphate source) }\end{array}$ \\
\hline A (A1 - A2) & 10 gram & 20 gram & 2 gram \\
\hline B (B1 - B2) & 10 gram & 2 gram & 0.2 gram \\
\hline C1 & 10 gram & - & - \\
\hline C2 & - & 20 gram & 2 gram \\
\hline C3 & - & - & - \\
\hline & & & \\
\hline
\end{tabular}




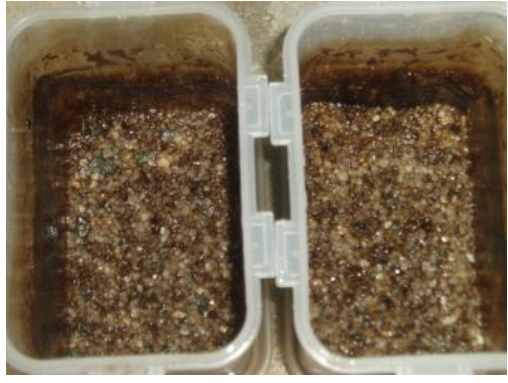

A : A1 - A2 (oil and fertilizer, high)

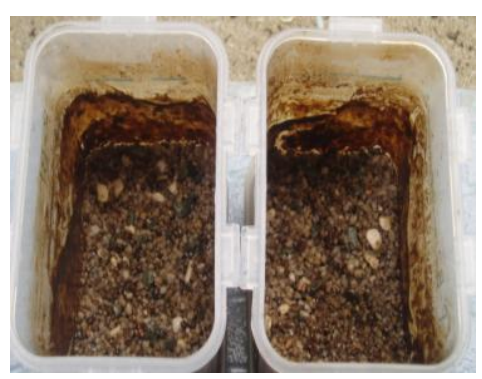

B : B1 - B2 (oil and fertilizer, low)

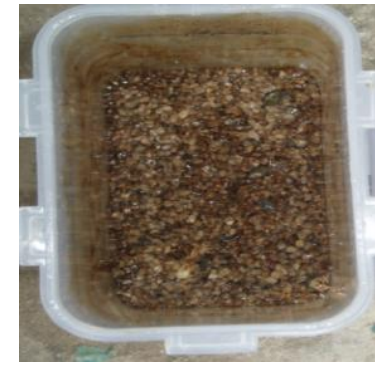

$\mathrm{C} 1$ : contain only oil

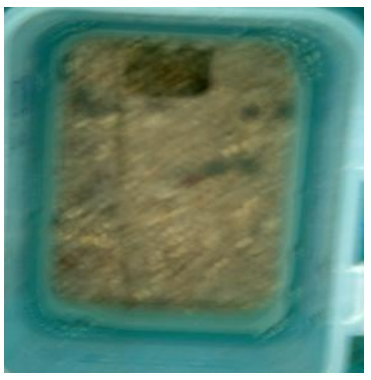

$\mathrm{C} 2$ : contain only fertilizer

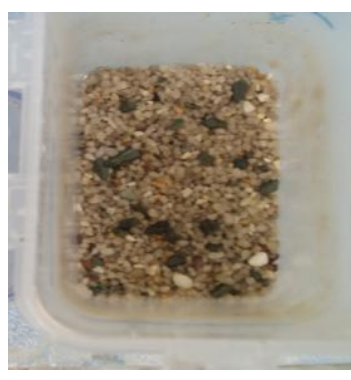

C3 : no oil and no fertilizer

Figure 3. Experimental design using a sieve and partially filled of gravel grains which coated crude oil and biostimulan from two different fertilizers and concentration (Super IB and Linster)

\subsection{Method for Extraction}

The samples were taken from tanks of 60 days and 90 days. Procedures for experiment was used gravel which contamination Arabian light crude oil then make DNA extraction and oil extraction. Community of bacteria was determined by DGGE, Clone library and sequence; remaining of hydrocarbon compounds was determined by GCMS. DNA extraction method by using beads beating and kit (Soil DNA Extraction from Nippon gene), Supplemented with Triton-X 100 (1\%) and Skim milk (10\%); DGGE analyze method by using primer $27 \mathrm{~F}$ and $1492 \mathrm{R}, 341 \mathrm{~F}-\mathrm{GC}$ and 518 R (Muyzer, 1999)

\subsection{Extraction of DNA}

DNA was extracted by using beads beating and kit for soil. Nucleic acids was precipitated by centrifuging at $15000 \mathrm{rpm}$ for $10 \mathrm{~min}$., washed with 1 $\mathrm{ml}$ of a $70 \%(\mathrm{v} / \mathrm{v})$ ethanol solution and dissolved in $0.2 \mathrm{ml}$ of a TE buffer containing $100 \mathrm{mg}$ of RNase. This solution was incubated at $37^{0} \mathrm{C}$ for $1 \mathrm{~h}$ and finally separated in a QIA-quick spin column (QiAgen). The purity and quantity of DNA were examined by recording its UV absorption spectrum. DNA extracts and the partial region amplification of $16 \mathrm{~S}$ rDNA was amplified by PCR using 30 cycles. The primers used for DNA amplification were $27 \mathrm{~F}$ and $1492 \mathrm{R}$. The PCR products were purified by spin column chromatography (QiAgen kit) and were analyzed directly by DGGE.

\subsection{Denaturing Gradient Gel Electrophoresis (DGGE) of the PCR products \\ PCR primers P2 and P3 (Muyzer,} 1999) were used to amplify the variable V3 region of bacterial $16 \mathrm{~S}$ rDNA 
(corresponding to positions $341-534$ in the Escherichia coli rRNA sequence) connected to the GC clamp. PCR was performed as described previously (Watanabe et al., 1998). Amplification of the PCR products of expected size was confirmed by electrophoresis, $1.5 \%$ (w/v) agarose gel in a TBE buffer. DGGE was performed with DCode instrument (BioRad) according to the manufacturer's instructions. Gels were made using a gradient of denaturants between $38 \%$ (containing $2.66 \mathrm{M}$ urea and $15.2 \%(\mathrm{w} / \mathrm{v})$ formamide) and $58 \%$ (containing $4.06 \mathrm{M}$ urea and $23.2(\mathrm{w} / \mathrm{v})$ formamide). $10 \mathrm{ml}$ of the PCR-amplified mixture was subjected to electrophoresis in $10 \%$ (w/v) polyacrylamide gel at 200 $\mathrm{V}$ for $3.5 \mathrm{~h}$ at a running temperature of $60^{\circ} \mathrm{C}$. The gel was then stained with Ethidium-Bromide for 30 min according to the manufacturer's instructions (see Result, Figure 4, 5, and 6). The strong DGGE bands were excised with a razor blade and soaked in $100 \mu$ l of TE buffer, and its DNA sequence was determined as described previously (Watanabe $e t$ al., 1998). Purified DNA was sequenced with an ABI-Prism and the resulting sequences were compared with the compilation of $16 \mathrm{~S}$ rDNA genes available in GenBank nucleotide library by a BLAST search through the NCBI.

\subsection{Sequence Determination of $16 \mathrm{~S}$ rDNA}

Partial nucleotide sequences of 16S rDNA corresponding to positions 37-1370 of the E. coli rRNA sequence were amplified according to the method of Edwards et al. (1989). The sequence of the 16S rDNA was determined with a Dye terminator sequencing kit (Applied Biosystems), and the product was analyzed with an ABI Prism DNA sequencer (Applied Biosystems). The nucleotide sequence data reported in this paper are listed in Table 2 and 3.

\subsection{Analysis of the oil samples}

The oil from gravel was extracted by hexane, then shaking and removing to other vial containing sodium sulfate. An analysis of the crude oil by gas chromatography-mass spectrometry was performed by using a QP-5000 instrument fitted with a fused silica capillary column. The temperature program gave a 2 -min hold at $50^{\circ} \mathrm{C}$, an increase to $300^{\circ} \mathrm{C} / \mathrm{min}$ at $6^{0} \mathrm{C} / \mathrm{min}$ and a 16-min hold at $300^{\circ} \mathrm{C}$. The injection volume was $1 \mu 1$, and the carrier gas was helium $(1.7 \mathrm{ml} / \mathrm{min})$. The mass-selective detector was operated in the scan mode to obtain spectral data for identifying the compounds and in the selected ion monitoring (SIM) mode for quantifying the target compounds. GC/MS was performed according to the method of Wang et al. (1998) and all values obtained by the instrumental analyses were normalized to that of $17 \alpha(\mathrm{H})$, 21ß(H)-hopane (Prince et al., 1994).

\subsection{Clone library analyze}

In order to explore potential reasons for the unexpected similarity of the relative abundances of the ribotypes in the two libraries, we investigated whether the amplification process essentially stopped soon after the $18^{\text {th }}$ cycle due to reagent limitation (Acinas $e t$ al., 2003) Using quantitative PCR (qPCR), we determined the kinetics of product accumulation mimicking PCR conditions utilized for clone library contruction $\quad(100 \quad \mathrm{nM}$ primer concentration and 5 to $10 \mathrm{ng}$ DNA). The results show that the reaction was saturated around the 30th cycle, indicating that the modified library underwent $\sim 12$ additional cycles of amplification. Even a minor difference in amplification efficiency among different templates would have resulted in a noticeable difference in ribotype abundance in the two libraries. 


\section{RESULT AND DISCUSSION}

Many microorganisms capable of degrading petroleum components in natural environment and the bacteria play a major role in degradation of oil spill. This research is bioremediation experimental which use Arabian light crude oil and Biostimulation as bioremediation strategy. Biostimulation with fertilizers Super IB and Linster as nutrients $(\mathrm{N}$ and $\mathrm{P})$ was done to analyze biodegradation of hydrocarbon compounds: Naphthalene, Alkane, Fluorene, Phenanthrene, Dibenzothiophene, as petroleum polynuclear aromatic hydrocarbons (PAHs) and mixture (PAHmix). Objective of this research is to monitor the changes of microbes succession in Pari Island experiment and which microbe is stimulated by addition of nutrient. The results showed the number of DGGE band indicate that diversity increase in early experiment then decrease in late stage (Figure 4). In tanks experiment on 60 days found 5 species and 90 days found 7 species which have similarity about $90-99 \%$ to their closest taxa by homology Blast search and have suspected as new species (Table 2). The species also showed on clone library (Alcanivorax, Marinobacter and Prosthecochloris) (see Table 3) and in semi enclosed system (Figure 6), but others species showed with small number. Sample enrichment without hydrocarbon source was used as control (0 day) which compared to sample enrichment contain hydrocarbon degrading bacteria, showed that number of colonies are higher than number of colonies which grown on hydrocarbon source (Figure 4, from tanks experiment which 28 days incubation comparing to 60-90 days; and Figure 6, from semi enclosed system while comparing 0 day to 60-150 days incubation). However the numbers of bacteria were lower in enrichment containing hydrocarbon because the bacteria became selective and difficult growth on hydrocarbon source.

\subsection{Denaturing gradient gel electrophoresis (DGGE)}

The bacterium which was showed positive growth on hydrocarbon compound (PAHmix) such as Alkane, Fluorene, Naphthalene, Phenanthrene, and Dibenzothiophene, were identified then analyzed by DGGE of polymerase chain reaction (PCR)-amplified $16 \mathrm{~S}$ rDNA fragments (Figure 4 and 5). If the proper tests are chosen and conducted aseptically, the bacterium can be identified to the genus stage in this particular laboratory. Applications include evaluation of water quality and discovery of new microbial species was studied in this particular experiment. This technique would be useful if a certain bacterium was known as a degrading bacteria and it was required to check to see whether it was present (Fandino et al., 2001).

\subsection{S rDNA gene sequence}

Based on DNA extracts and band of DGGE, 16S rDNA which amplified by PCR using 30 cycles and primers U515f and U1492r was got sequence result and listed in Table 2. Many species of bacteria from 60 and 90 days incubation was found and have similarity about $90-99 \%$ by homology Blast search. The bacteria can grow and degrade hydrocarbon compound likes Alkane, Fluorene, Naphthalene, Phenanthrene, and Dibenzothiophene. DGGE has been shown to detect differences in the melting behavior of small DNA fragments (200-700 bp) that differ by as little as single base substitution. This method separates DNA fragments of the same lengths on 


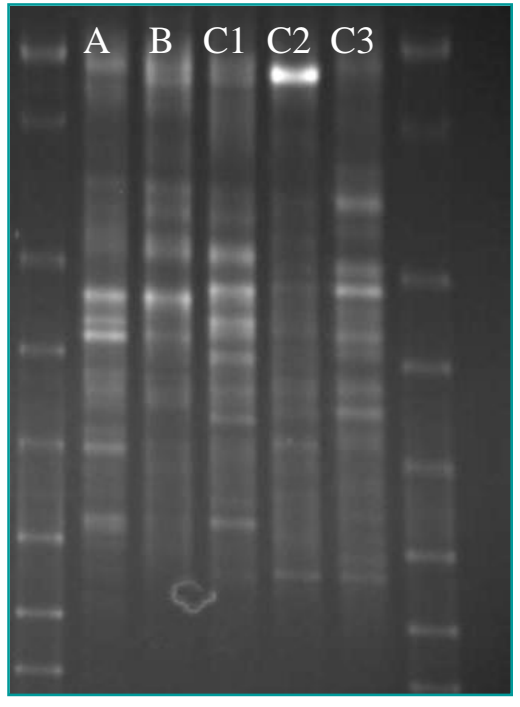

$28 \mathrm{~d}$

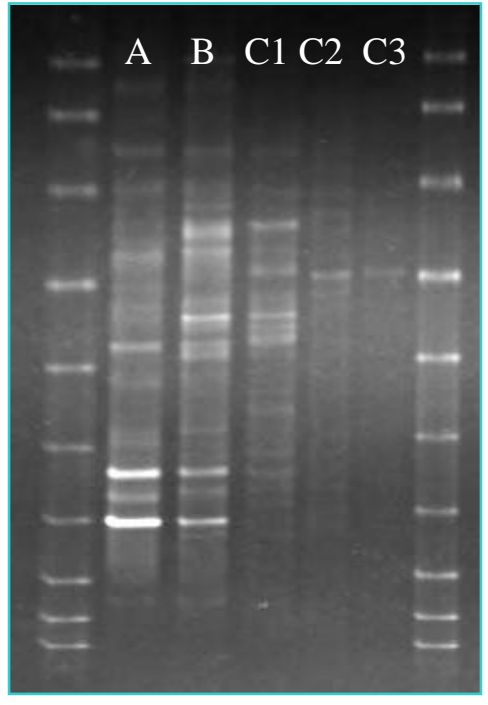

$60 \mathrm{~d}$

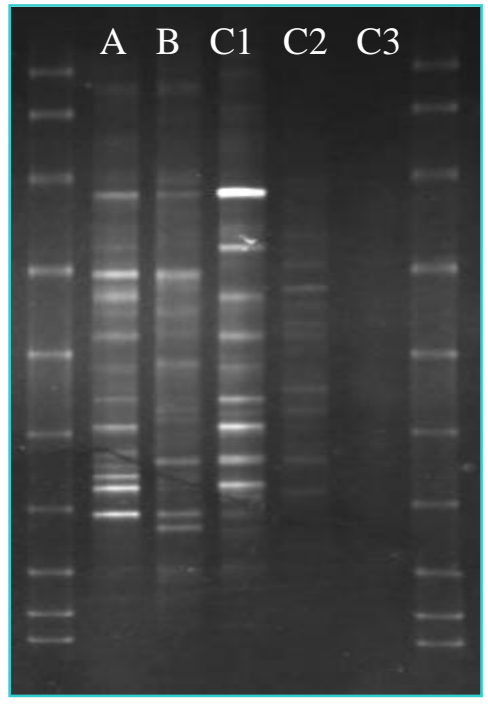

$90 \mathrm{~d}$

Lane A, bacteria grown in seawater supplemented oil and fertilizer with high concentration.

Lane B, bacteria grown in seawater supplemented oil and fertilizer with low concentration.

Lane C1, bacteria grown in seawater supplemented only oil.

Lane C2, bacteria grown in seawater supplemented only fertilizer.

Lane C3, bacteria grown in seawater supplemented no oil and no fertilizer.

Figure 4. Result of DGGE from 28, 60 and 90 days incubation in tanks experiment. Effect of nutrient and process manipulation on microbe diversity, Number of band in latest experiment indicate that diversity increased in early experiment then decrease in late stage and showed the dominant species.

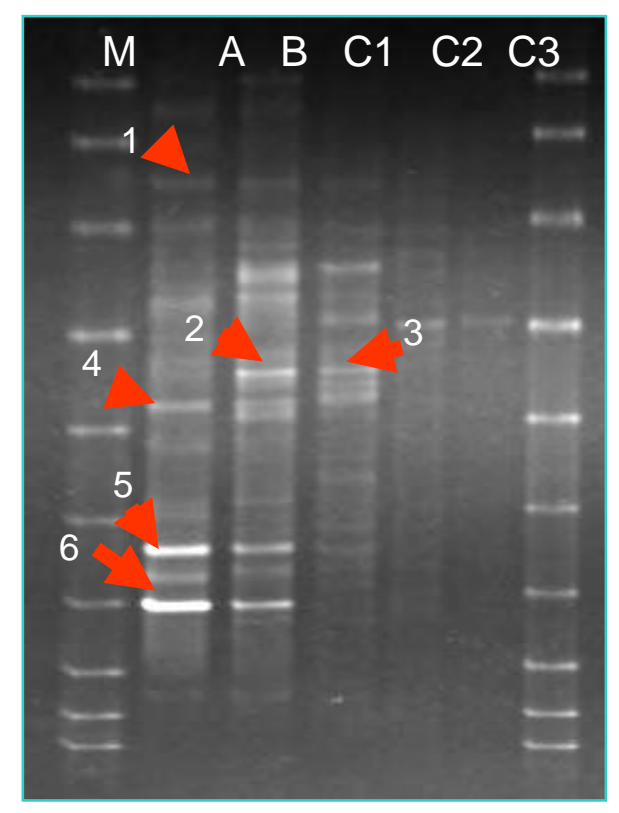

$60 \mathrm{~d}$

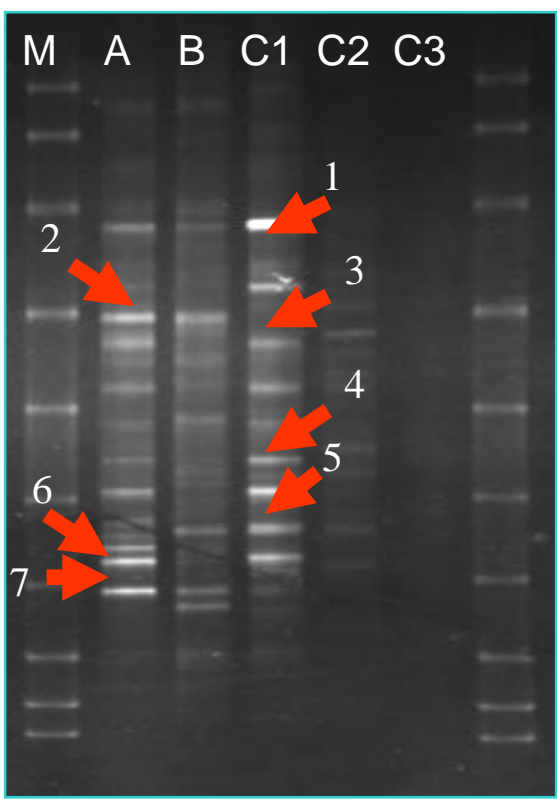

$90 \mathrm{~d}$

Figure 5. DGGE profiles of partial 16S rDNA fragments showing bacterial populations grown in sea water (tanks experiment) based media. $\mathrm{M}$ is marker 
Table 2. Many species of bacteria from 60 and 90 days incubation was found and have similarity about $90-99 \%$ by homology Blast search

\begin{tabular}{|c|l|l|}
\hline No. & \multicolumn{1}{|c|}{ 60 days } & \multicolumn{1}{c|}{ 90 days } \\
\hline 1 & Thiomicrospira arctica (94) & Alcanivorax borkumensis (100) \\
\hline 2 & Pelobacter masseliensis (91). & Marinobacter aquaeolei (96) \\
\hline 3 & Pseudoalteromonas sp (93). & Oceanospirillum pusilum (99) \\
\hline 4 & Haplosporidium sp. (88). & Ruegeria sp. (99) \\
\hline 5 & Prosthecochloris sp. (99). & Chlorobium bathyomarinum (100) \\
\hline 6 & Prosthecochloris aestuarii (100). & Gemmatimonas aurantiaca (92) \\
\hline 7 & & Prosthecochloris aestuarii (99) \\
\hline
\end{tabular}

the basis off differences in base-pair sequences, and was recently adapted from detection of point mutations, to being used on a mixture of $16 \mathrm{~S}$ rDNA gene fragments amplified by PCR from complex environmental DNA samples.

Blast search of the complete $16 \mathrm{~S}$ rDNA sequence for strain of hydrocarbon degrading bacteria showed the genus have high similarity with a cluster of partially sequenced. It also showed the highest level of sequence similarity to a number of characterized bacteria from the clone library. Our clone library analysis has included all named representatives of the genus Alcanivorax, Marinobacter, Prosthecochloris and others (Table 3).

The biodegradation of hydrocarbon compounds was stimulated when fertilizers were supplemented. In those conditions, Alcanivorax, Marinobacter and Prosthecochloris were best hydrocarbons degrading bacteria (on PAH mix) comparing with several bacteria (showed in Figure 6). But growth of that both bacteria on hydrocarbon or heavy oil were not particularly rapid in comparison with other hydrocarbon degrading bacteria.

The strains of Alcanivorax, Marinobacter and Prosthecochloris have degraded of crude oil, and its components were analyzed by gas chromatography/ mass spectrometry (GC/MS). The addition of fertilizers promoted the degradation of certain components of crude oil: about
$70 \%$ - more than $90 \%$ of Naphthalene (NAP) and n-Alkane, and more than $70 \%$ of (alkyl) naphthalene and alkane were degraded in 90 days. The degradation of Phenanthrene (PHE), Dibenzothiophene (DBT), Fluorene (FLU) and their alkylsubstituted derivatives was less extensive, being $20 \%$ to $50 \%$ (see Figure 7 and 8 ). Alcanivorax also degraded oil in this research, like did as observation by many researchers.

Most pollutant-degrading microorganisms isolated and characterized in the laboratory are now thought to make a minor contribution to bioremediation. Another difficulty is that no two environmental problems occur under completely identical conditions, for example, variations occur in the types and amounts of pollutants, climate conditions and hydrogeodynamics. These difficulties have caused the bioremediation field to lag behind knowledge based technologies that are governed by common rationales (Watanabe, 2001).

The addition of nitrogen and phosphorus fertilizers stimulates the biodegradations of petroleum. In general, small hydrocarbon molecules are more easily biodegraded than larger ones, and aromatics are degraded at a much slower rate than that of alkanes in marine environments (Harayama et al., 1999). Bioremediation of spilled oil is a powerful tool for in situ cleaning of oli- 
Table 3. Clone library analysis from Pari island seawater (256 PCR amplified)

H-28

H-60

H-90

\begin{tabular}{|c|c|c|c|c|c|c|c|c|c|c|}
\hline \multicolumn{5}{|c|}{$\mathrm{H}-\mathrm{O}$} & & & & & & \\
\hline$\%$ clone detected & & A & B & $\mathbf{C}$ & $\mathbf{A}$ & B & $\mathbf{C}$ & $\mathbf{A}$ & B & $\mathrm{C}$ \\
\hline Alcanivorax & $\mathbf{0}$ & 7 & $\mathbf{0}$ & $\mathbf{0}$ & $\underline{\mathbf{0}}$ & $\underline{2}$ & $\underline{1}$ & $\underline{8}$ & $\underline{\mathbf{3}}$ & $\underline{31}$ \\
\hline Cycloclasticus & $\mathbf{0}$ & 14 & 11 & 2 & 1 & 1 & 3 & $\mathbf{0}$ & 1 & $\mathbf{0}$ \\
\hline Marinobacter & $\mathbf{0}$ & 12 & 8 & 6 & $\underline{\mathbf{3}}$ & $\underline{1}$ & $\underline{4}$ & 19 & $\underline{\mathbf{3}}$ & $\underline{2}$ \\
\hline Oleiphilus & $\mathbf{0}$ & 1 & 1 & $\mathbf{0}$ & $\mathbf{0}$ & $\mathbf{0}$ & 1 & $\mathbf{0}$ & $\mathbf{0}$ & $\mathbf{0}$ \\
\hline Oleispira & $\mathbf{0}$ & $\mathbf{0}$ & 1 & $\mathbf{0}$ & 0 & $\mathbf{0}$ & $\mathbf{0}$ & $\mathbf{0}$ & 0 & $\mathbf{0}$ \\
\hline Roseobacter & 0 & 0 & 0 & 0 & 1 & 0 & 0 & 0 & 1 & $\mathbf{0}$ \\
\hline Stappia & 0 & 0 & $\mathbf{0}$ & $\mathbf{0}$ & 1 & 0 & 1 & 0 & 0 & $\mathbf{0}$ \\
\hline Marinobacterium & $\mathbf{0}$ & 1 & 2 & 0 & 0 & 0 & $\mathbf{0}$ & 1 & $\mathbf{0}$ & 5 \\
\hline Thalassospira & $\mathbf{0}$ & 1 & $\mathbf{0}$ & $\mathbf{0}$ & 0 & $\mathbf{0}$ & 1 & $\mathbf{0}$ & 1 & 1 \\
\hline Prosthecochloris & $\mathbf{0}$ & $\mathbf{0}$ & $\mathbf{0}$ & $\mathbf{0}$ & 39 & $\underline{\mathbf{8}}$ & $\underline{\mathbf{0}}$ & $\underline{20}$ & $\underline{5}$ & $\underline{\mathbf{3}}$ \\
\hline Desulfobacteraceae* & 1 & $\mathbf{0}$ & $\mathbf{0}$ & $\mathbf{0}$ & 8 & 23 & 3 & $\mathbf{0}$ & $\mathbf{0}$ & $\mathbf{0}$ \\
\hline Rhodobacteraceae* & 39 & $\mathbf{0}$ & $\mathbf{0}$ & $\mathbf{0}$ & 11 & 5 & $\mathbf{0}$ & $\mathbf{0}$ & $\mathbf{0}$ & $\mathbf{0}$ \\
\hline Others & 61 & 64 & 77 & 92 & 36 & 60 & 88 & 52 & 87 & 58 \\
\hline
\end{tabular}

*Unclassified

polluted beaches. Application of fertilizers promotes the growth of oildegrading bacteria and hence the rate of biodegradation of crude oil. Changes in microbial populations during bioremediation of crude oil have been analyzed by molecular techniques (Kasai et al., 2002). Some marine bacteria have previously been reported to be PAH degraders, these bacteria include members of the genera Cycloclasticus, Flavobacterium, Moraxella, Pseudomonas, Sphingomonas and Vibrio (Dyksterhouse et al., 1995; Gauthier et al., 1992; Zylstra et al., 19977; Syutsubo et al., 2001).
However the activities of these organisms in the natural environment remain unknown. In this study we analyzed the major players in the bioremediation of petroleum PAHs by using experiment tanks and semi enclosed system that are more similar to the natural environment. The experiment tanks and semi enclosed system indicated that degradation of substituted aromatic hydrocarbons did occur and that some other bacterial populations were involved in the degradation of such aromatic hydrocarbons. It is important to identify these bacterial populations and 

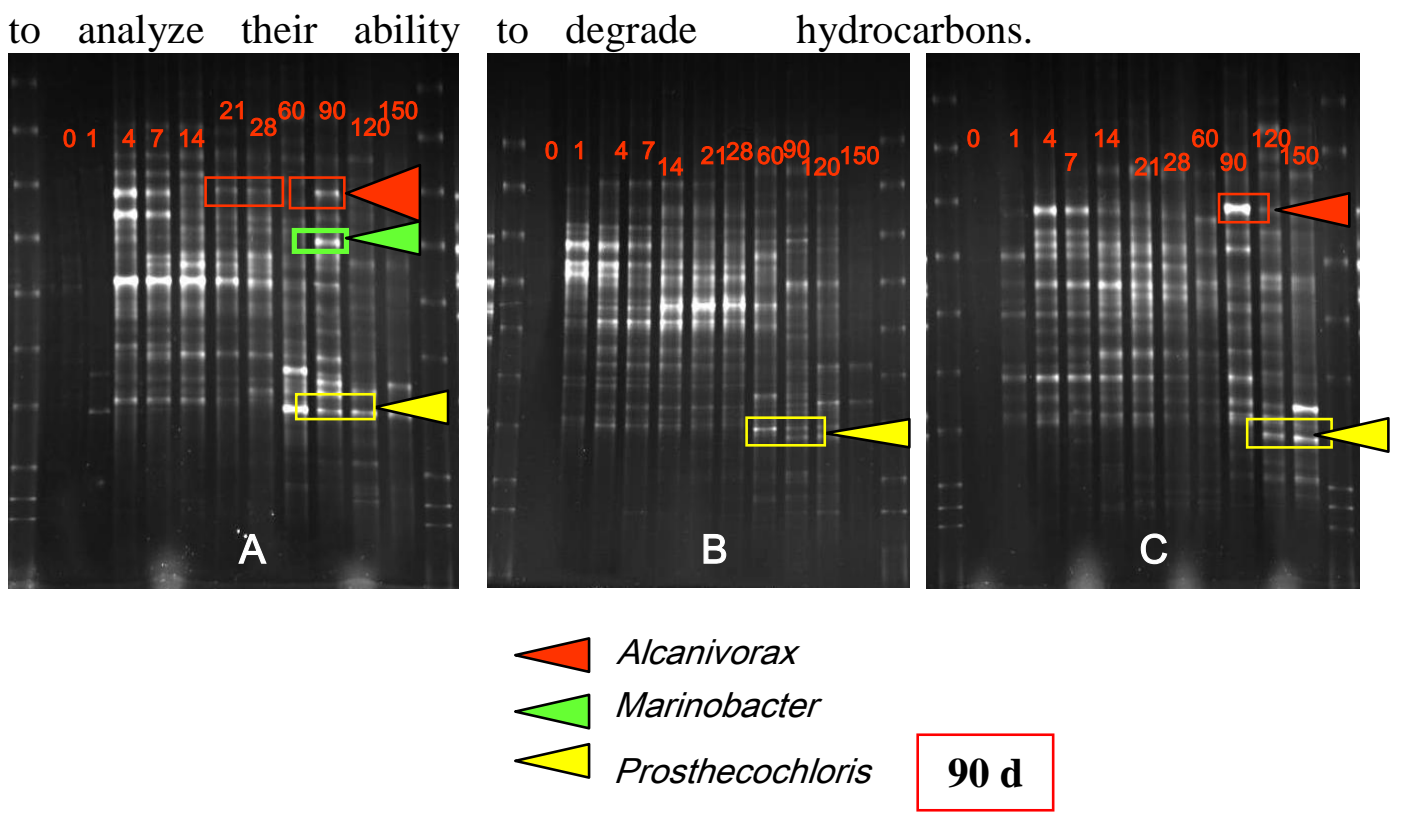

Lane 0-150, the bacteria grown in seawater supplemented oil with fertilizer as $0-150$ day.

A, bacteria grown in seawater supplemented oil and fertilizer high concentration.

B, bacteria grown in seawater supplemented oil and fertilizer low concentration.

C, bacteria grown in seawater supplemented no oil and no fertilizer.

Figure 6. Bacterial community analysis by DGGE from semi enclosed system (0-150 day incubation). These results found 3 species dominant, which same position and have small number compare with DGGE result from tanks experiment (by Atsushi Yamazoe)

A

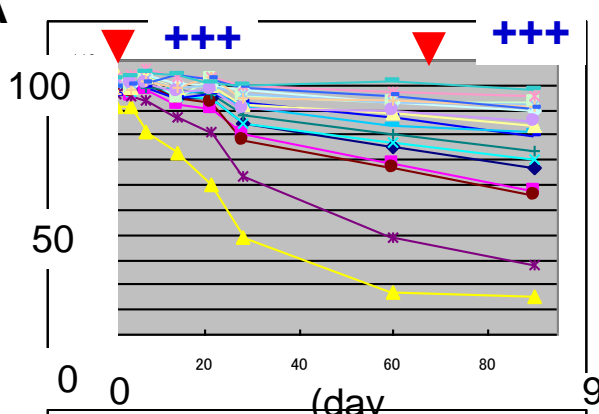

B

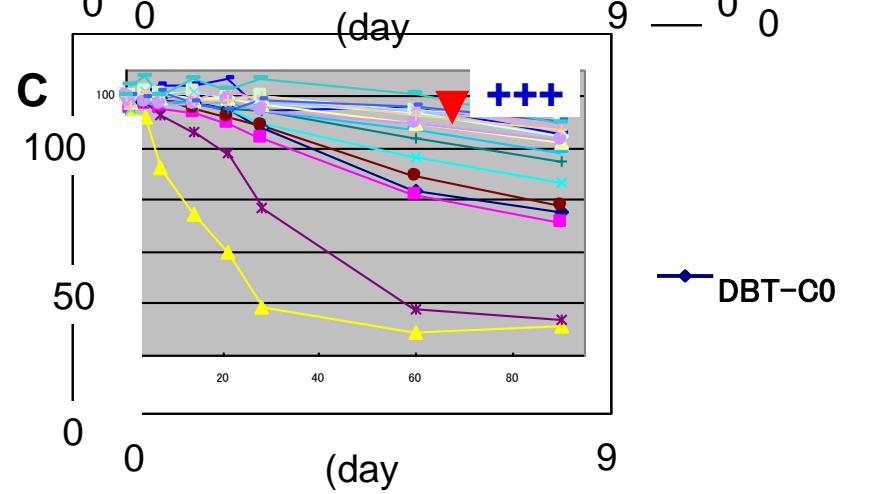

(day

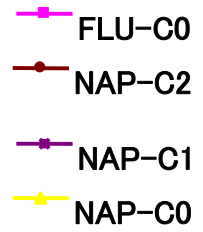

9

$\begin{array}{rr}- \text { NAP-C3 } & \text { DBT-C1 } \\ - \text { NAP-C4 } & \text { DBT-C2 } \\ - \text { FLU-C1 } & \text { DBT-C3 } \\ \text { FLU-C2 } & - \text { PHE-C0 } \\ \text { FLU-C3 } & - \text { PHE-C1 } \\ & - \text { PHE-C2 } \\ & - \text { PHE-C3 } \\ & \text { PHE-C4 }\end{array}$

Remaining (\%)

Figure 7. GC-MS analysis for degradation of Poly Aromatic Hydrocarbon by microbial community on 0-90 days (by Masahito Suzuki) 
A

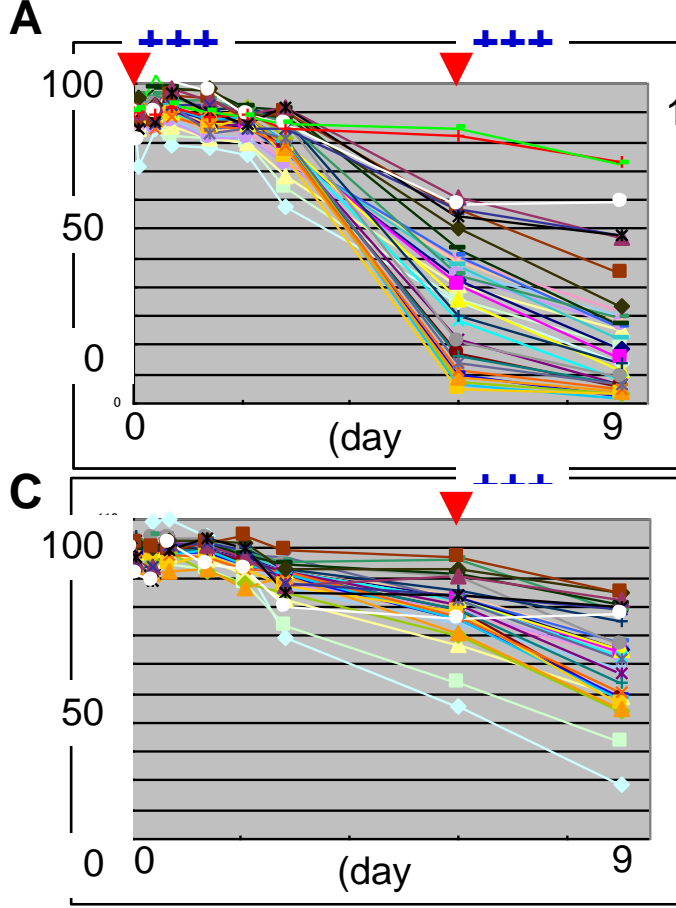

B

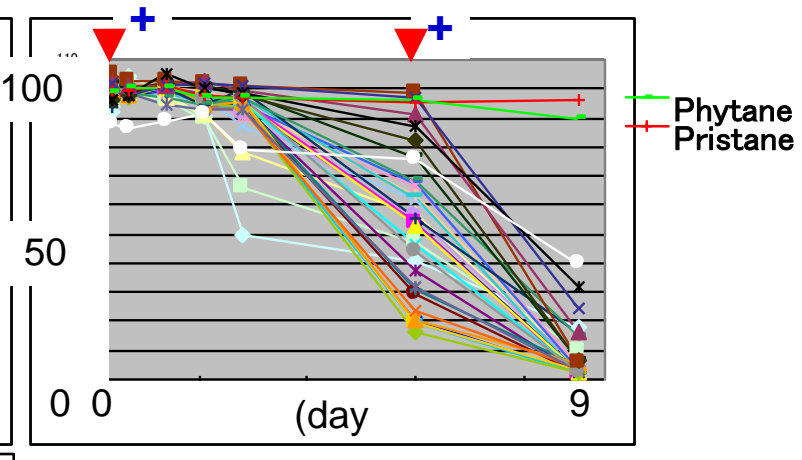

Remaining (\%)

Figure 8. GC-MS analysis for degradation of ALKANE by microbial community on 090 days (by Masahito Suzuki)

\section{CONCLUSION}

The strains of Alcanivorax, Marinobacter and Prosthecochloris as genuses of hydrocarbon degrading marine bacteria were identified, and few of them were probably a new species which need further studies. Each band in a DGGE gel was believed to be representing a single species/genus although heterogeneity of rDNA genes within a single species was reported. The profile of microbial community as expressed by DGGE was different among treatment. Addition of fertilizer was affect to microbial community, however the effect of fertilizer did not consistence. Microbes playing role in the biodegradation of crude oil might be diverse.

\section{ACKNOWLEDGEMENT}

We are grateful to Dr. Atsushi Yamazoe, Dr. Masahito Suzuki and Prof. Dr. Shigeaki Harayama for their kind as supervision to this work. This work was part of collaboration research between Indonesia and Japan for identification of hydrocarbon degrading bacteria, supported by NITE and NEDO Japan.

\section{REFERENCES}

Acinas, S.G., R.S Rupavtarm, V.K. Ceraj and M.F. Polz. 2005. PCR-Induced Sequence Artifacts and Bias: Insights from Comparison of Two 16S rRna Clone Libraries Constructed from the Same Sample. Applied and Environmental Microbiology, 71(12):8966-8969. 
Atlas, R.M. 1995. Bioremediation of petroleum pollutants. International Biodeterioration and Biodegradation, 35:317-327.

Dyksterhouse, S.E., J.P. Gray, R.P. Herwig, J.C. Lara and J.T. Staley. 1995. Cycloclasticus pugetii gen. nov., sp. nov., an aromatic hydrocarbon-degrading bacterium from marine sediments. Int. J. Syst. Bacteriol., 45:116-123.

Edwards, U., T. Rogall, H. Blocker, M. Emde, and E.C. Bottger. 1989. Isolation and Direct Complete Nucleotide Determination of Entire Genes. Characterization of a Gene Coding for 16S Ribosomal RNA. Nucleic Acids Res., 17:7843-7853.

Fandino, L.B., L. Riemann, G.F. Steward, R.A. Long, and F. Azam. 2001. Variations in Bacterial Community Structure During a Dinoflagellate Bloom Analyzed by DGGE and 16S rDNA Sequencing. Aquatic Microbial Ecology. Aquat. Microb. Ecol., 23:119-130.

Gauthier, M. J., B. Lafay, R. Christen, L. Fernandez, M. Acquaviva, P. Bonin and J. C. Bertrand. 1992. Marinobacter

hydrocarbonoclastycus gen. nov., sp. nov., a new, extremely halotolerant, hydrocarbon-degrading marine bacterium. Int. J. Syst. Bacteriol., 42:568-576.

Harayama, S., H. Kishira, Y. Kasai and K. Shutsubo. 1999. Petroleum Biodegradation in Marine Environments. J. Mol. Microbiol. Biotechnol., 1(1):63-70.

Kasai, Y., H. Kishira, T. Sasaki, K. Syutsubo, K. Watanabe and S. Harayama. 2002. Predominant Growth of Alcanivorax Strains in Oil Contaminated and Nutrient Supplemented Sea Water. Environmental Microbiology, 4(3):141-147.
Kasai, Y., H. Kishira and S. Harayama. 2002. Bacteria belonging to the Genus Cycloclasticus Play a primary Role in the degradation of aromatic Hydrocarbons released in a Marine Environment. Apll. And Environmental Microb., 68(11): 5625-5633

Lopez-Lopez, A., $\quad$ M.J.Pujalte, S.Benlloch, M.Mata-Roig, R.Rosello-Mora, E.Garay and F.Rodriguez-Valera (2002). Thalassospira lucentensis gen. nov., sp. Nov., a new marine member of the $\alpha$-Proteobacteria. IJSEM (52):1277-1283.

MacNaughton, S.J., J.R. Stephen, A.D.Venosa, G.A.Davis, Y.J. Chang, and D.C. White. 1999. Microbial Population Changes during Bioremediation of an Experimental Oil Spill. Applied and Environmental Microbiology, 65(8):3566-3574.

Maki, H., T. Sasaki, E. Sasaki, M. Ishihara, M. Goto, and S. Harayama. 1999. Use of Wastewater Sludge for the Amendment of Crude Oil Bioremediation in Meso-scale Beach Simulating Tanks. Environ. Technol., 20:625-632.

Marmur, J. 1961. A Procedure for the Isolation of Deoxyribonucleic Acid from Micro-organisms. J.Mol.Biol., 3:208-218.

Muyzer, G. 1999. DGGE/TGGE a method for identifying genes from natural ecosystems. Current Opinion Microbiol., 2:317-322.

Prince, R.C., D.L. Elmendorf, J.R. Lute, C.S. Hsu, C.E. Haith, and J.D.Senius. $1994 . \quad 17 \alpha(H), 21 \beta(H)-$ hopane as a Conserved Internal Marker for Estimating the Biodegradation of Crude Oil. Environ. Sci. Technol., 28:142-145. 
Syutsubo, K., H. Kishira, and S. Harayama. 2001. Development of specific oligonucleotide probes for the identification and in situ detection of hydrocarbon-degrading Alcanivorax strains. Environ. Microbiol. 36: 676-681

Watanabe, K., S. Yamamoto, S. Hino, and S. Harayama. 1998. Population Dynamics of Phenol-Degrading Bacteria in Activated Sludge Determined by gyrB targeted Quantitative PCR. Appl. Environ. Microbiol., 64:1203-1209.

Watanabe, K. 2001. Microorganisms Relevant to Bioremediation. Current Opinion in Biotechnology, 12:237241.

Watanabe, K., and N. Hamamura. 2003. Molecular and Physiological Approaches to Understanding the Ecology of Pollutant Degradation. Current Opinion in Biotechnology, 14:289-295.

Wang, Z., M. Fingas, S. Blenkinshopp, G. Sergy, M. Landriault, L. Sigouin,
J. Foght, K. Semple, and D.W. Westlake. 1998. Comparison of oil compositions changes due to biodegradation and physical weathering in different oils. $J$. Chromatogr. A. 809:89-107.

Watanabe, K., M. Tomomichi, A. Hiroki. 2006. Impacts of Bioremediation Schemes on Bacterial Population in Naphthalene-Contaminated Marine Sediments. Biodegradation, 17(3): 227-235.

Yakimov, M.M, P.N.Golyshin, S.Lang, E.R.B. Moore, W.Abraham, H.Lunsdorf and K.N. Timmis (1998). Alcanivorax borkumensis gen. nov., sp. Nov., a new, hydrocarbon-degrading and surfactant-producing marine bacterium. IJSB (48): 339348.Zylstra, G. J., E. Kim, and A. K. Goyal. 1997. Comparative molecular analysis of genes for polycyclic aromatic hydrocarbon degradation. Genet. Eng. 19:257-269. 